\title{
Penerapan Model Flipped-Classroom untuk Meningkatkan Performa Guru pada Pelajaran Bahasa Inggris (Studi Kasus di SMA Negeri 1 Narmada, Nusa Tenggara Barat)
}

\author{
Manikowati9 \\ manikowati@kemdikbud.go.id
}

\begin{abstract}
Learning time reduction in SMA N 1 Narmada as an earthquake effect became the background of flipped-classroom implementation. The research is to: 1) analyze teacher's preparation in implementing a flipped-classroom; 2) analyze teacher's performance in it; 3) analyze the uses of multi media in it; and 4) suggest or recommend to enhance it. The research used qualitative method by studying teacher's lesson plan, observing the implementation, and interviewing the teacher and the headmaster. To gain the data, the researcher used instruments like the teacher's lesson plan, the observation and interview sheets. From the investigation, the researcher concluded that: 1) the teacher was capable of preparing his teaching and learning activities, the flipped-classroom implementation was implicitly stated in his plan; 2) the teacher's performance in the process was enhanced. He could optimize the student's learning; 3) multi media used, video graphics dan powerpoint could be applied well; and 4) suggestion was given to the teacher to improve his teaching performance, including to learn more about the learning models. For the headmaster it was suggested to control the teachers' performance and conduct a teacher-parent program. Meanwhile, for BPMPK it was to be a good school-partner, especially in case of innovative learning models.
\end{abstract}

Keywords: Flipped Classroom, Multimedia, English, Lesson Plan, Teaching and Learning

\footnotetext{
${ }^{9}$ Balai Pengembangan Multimedia Pendidikan dan Kebudayaan (BPMPK) Kemendikbud
} 


\section{PENDAHULUAN}

B alai Pengembangan Multimedia Pendidikan dan Kebudayaan atau yang disingkat BPMPK merupakan salah satu unit pelaksana teknis Kementerian Pendidikan dan Kebudayaan yang memiliki tugas utama untuk melakukan pengembangan model pembelajaran berbasis multimedia. Untuk melaksanakan tugas tersebut, BPMPK melaksanakan fungsi antara lain implementasi.

Implementasi menurut Kamus Besar Bahasa Indonesia (KBBI) diartikan sebagai pelaksanaan atau penerapan. Lebih detil, menurut Jones (Mulyadi, 2015), implementasi yaitu "Those Activities directed toward putting a program into effect" (proses mewujudkan program hingga memperlihatkan hasilnya). Perwujudan tersebut dalam dilakukan oleh siapa pun dengan tujuan yang telah ditetapkan. Sebagaimana disampaikan oleh Horn (Tahir, 2014) yang mengartikan implementasi sebagai tindakantindakan yang dilakukan baik oleh individu-individu atau pejabat-pejabat atau kelompok-kelompok pemerintah atau swasta yang diarahkan pada pencapaian tujuan-tujuan yang telah digariskan dalam kebijakan. Dari ketiga sumber referensi tersebut, implementasi merupakan sebuah penerapan atau pelaksanaan untuk mencapai tujuan yang ditargetkan melalui sebuah mekanisme yang direncanakan dan dinyatakan dalam sebuah aksi atau tindakan riil.

Berhubungan dengan fungsi implementasi yang harus dilakukan BPMPK sebagai bagian dari tugas pengembangan model-model pembelajaran berbasis multimedia, maka target kebijakan implementasi yang hendak dicapai adalah meningkatnya performa pembelajaran dengan multimedia yang dimanfaatkan. Sebagaimana telah ditemukan oleh Tiari, Suryani, dan Suharno (2016) pada penelitiannya bahwa penerapan multimedia mampu meningkatkan motivasi belajar siswa SD. Dengan demikian, implementasi menurut pandangan BPMPK merupakan upaya penerapan model pembelajaran dengan memanfaatkan multimedia dalam proses belajar mengajar. Fungsi ini dilakukan dengan mekanisme mulai dari melaksanakan studi kelayakan sampai dengan pemantauan. Hasil rangkaian kegiatan implementasi tersebut selanjutnya dievaluasi sehingga dapat direkomendasikan peningkatan kualitas penerapan pada tahun-tahun berikutnya. Dengan kata lain, penelitian ini merupakan evaluasi formatif atas penerapan model pembelajaran dengan memanfaatkan multimedia pada proses belajar mengajar di satuan pendidikan, termasuk di SMA Negeri 1 Narmada, di Lombok Barat, Nusa Tenggara Barat.

SMA Negeri 1 Narmada merupakan salah satu sekolah binaan BPMPK, yang kemudian disebut sekolah model. Sekolah ini merupakan salah satu sekolah yang terkena dampak terparah gempa bumi Lombok beberapa waktu sebelumnya. $80 \%$ ruang pembelajaran tidak dapat digunakan untuk kegiatan belajar mengajar. Kurang lebih satu minggu tidak terdapat pembelajaran. Pembelajaran lumpuh total. Sebagai usaha pemulihan, pembelajaran pasca gempa di sekolah ini dilaksanakan dua shift, pagi dan siang dengan menggunakan beberapa tenda darurat yang dipasang di halaman sekolah. Hanya sedikit kelas yang bisa digunakan untuk proses pembelajaran, pun untuk mata pelajaran bahasa Inggris.

Bahasa Inggris, bagi guru maupun siswa merupakan salah satu mata pelajaran yang harus dikuasai. Pertama, mata pelajaran ini merupakan salah satu mata pelajaran yang diujikan dan menjadi penentu lolos tidaknya siswa ke jenjang berikutnya. Kedua, Bahasa Inggris merupakan bahasa asing yang untuk menguasainya dibutuhkan waktu ekstra. Apalagi di Lombok yang juga merupakan kawasan wisata, menguasai bahasa Inggris merupakan salah satu hal yang sebaiknya dilakukan. Untuk menguasainya dengan baik, diperlukan lingkungan belajar yang kondusif. Akan tetapi, terkena gempa 
merupakan bencana yang tidak bisa dielakkan. Untuk itu, guru perlu melakukan strategi pembelajaran yang terbaik.

Berkaitan dengan performa guru model di sekolah ini, Manikowati dan Utomo (2018) mendapati bahwa dari awal para guru model di sekolah ini berada pada level literasi. Artinya, para guru sudah sadar dengan karakteristik pembelajaran abad 21. Akan tetapi, kemampuan atau kompetensi TIK yang dimiliki masih memerlukan peningkatan. Pemberian bimbingan teknis berupa pengembangan media belajar dan penerapan model pembelajaran blended learning diharapkan memotivasi para guru untuk meningkatkan performa skill-nya, meskipun dalam kondisi pembelajaran yang berkurang waktunya.

Blended Learning merupakan model pembelajaran yang mengkolaborasikan antara pembelajaran online- dengan memanfaatkan jaringan internet dan pembelajaran offline- dengan melaksanakan tatap muka atau face to face (Staker \& Horn (2012) dalam Daryanto, 2015). Salah satu tipe blended-learning adalah flipped-classroom.

Flipped-classroom berasal dari dua kata flipped dan classroom. Flipped berarti terbalik sedangkan classroom berarti kelas. Dengan demikian, flipped-classroom artinya kelas terbalik. Bergman dan Sams (2013) mendeskripsikan flipped-classroom dengan membalik aktivitas pembelajaran. Aktivitas belajar yang biasa dilakukan di sekolah akan menjadi aktivitas pembelajaran di rumah. Begitu sebaliknya. Selanjutnya, Braseby (2014) membagi pelaksanaan flipped-classroom menjadi tiga tahapan, di rumah, di sekolah, dan di rumah lagi. Dalam pelaksanaan implementasinya, Millman (2012) telah menyampaikan strategi terbaik penerapan flipped-classroom terdapat pada procedural knowledge tanpa menghilangkan factual, conceptual, dan metacognitive knowledge.

Memperhatikan fenomena tersebut di atas, evaluasi terhadap penerapan model pembelajaran flipped-classroom dengan memanfaatkan multi media berbasis TIK ini bertujuan untuk: 1) mengetahui persiapan guru dalam menerapkan model pembelajaran flipped-classroom; 2) menganalisis performa guru dalam menerapkan model pembelajaran flipped-classroom; 3) menganalisis pemanfaatan multi media yang digunakan dalam menerapkan model pembelajaran flipped-classroom; dan 4) memberikan saran atau rekomendasi untuk menjaga kualitas penerapan flipped-classroom model.

\section{METODE PENELITIAN}

Penelitian ini dilaksanakan pada tanggal 27-29 September 2018 di SMA Negeri 1 Narmada, Nusa Tenggara Barat. Adapun metode penelitian yang digunakan dalam evaluasi penerapan model pembelajaran flipped-classroom ini adalah metode kualitatif. Data dari Rencana Pelaksanaan Pembelajaran (RPP), observasi dan wawancara dengan guru model merupakan data utama yang digunakan untuk menganalisis proses penerapan didukung dengan wawancara dengan kepala sekolah. Hasil analisis datanya selanjutnya digunakan untuk memberikan rekomendasi kepada kepala sekolah, guru, maupun BPMPK sendiri untuk meningkatkan kualitas penerapannya.

Untuk memperoleh data tersebut, tiga instrumen yang digunakan adalah dokumen RPP guru model, lembar observasi, dan panduan wawancara. RPP digunakan untuk menganalisis kesiapan guru model dalam melakukan pembelajaran dan menganalisis kesiapan media yang dimanfaatkan untuk mendukung pembelajaran (procedural dan factual knowledge). Lembar observasi digunakan untuk menganalisis proses pembelajaran yang diselenggarakan oleh guru model (procedural, factual, conceptual, dan metakognition knowledge). Sementara, wawancara digunakan untuk mengetahui 
tingkat kesulitan guru model dalam menerapkan model pembelajaran flipped-classroom dan pemanfaatan medianya (procedural dan conceptual knowleged). Terakhir, wawancara dengan kepala sekolah untuk mengetahui tingkat kompetensi guru modelnya (factual dan conceptual knowledge). Dengan demikian, penelitian ini menggunakan triangulasi sumber data, dokumen, guru, dan kepala sekolah. Berikut adalah pola pemerolehan data dari triangulasi.

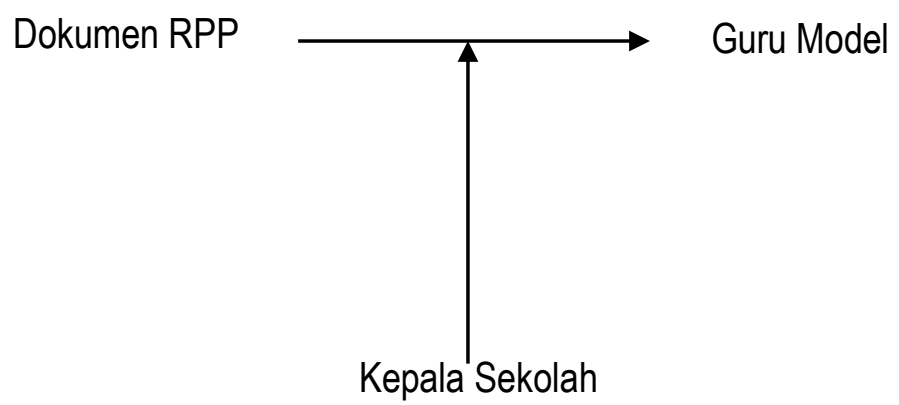

Gambar 1. Triangulasi Sumber Data Penelitian

\section{HASIL DAN PEMBAHASAN}

Sebelum peneliti mendeskripsikan hasil penemuan yang diperoleh, peneliti menyampaikan terlebih dahulu rangkaian implementasi model pembelajaran yang diterapkan dengan memanfaatkan multimedia. Berikut adalah gambaran mekanisme implementasi di SMA Negeri 1 Narmada, Nusa Tenggara Barat.

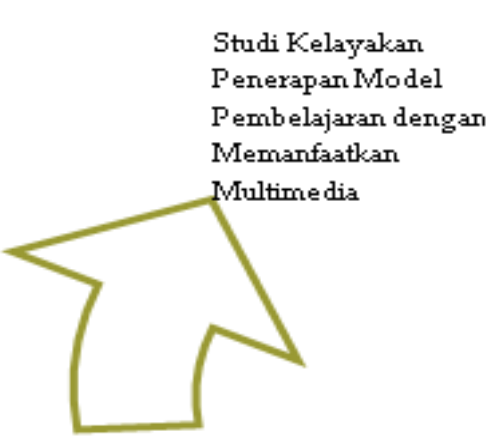

Pemantauan

Penerapan Model

Pembelajaran dengan

Memanfaatkan

Multimedia

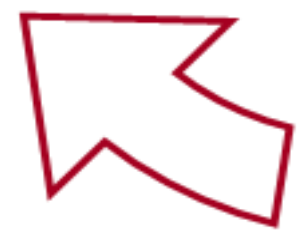

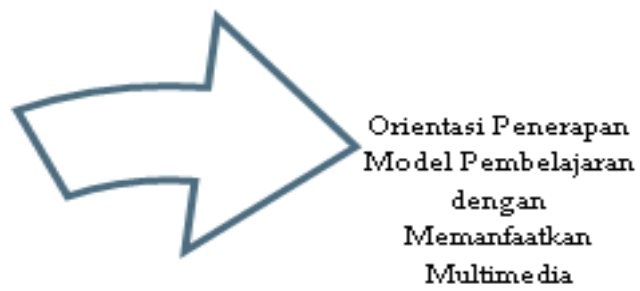

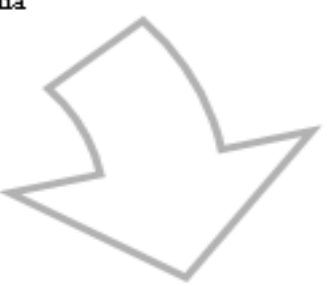

Sosialisasi Penerapan Model Pembelajaran dengan

Memanfaatkan

Multimedia

Fasilitasi Penerapan Model Pembelajaran dengan Memanfaatkan Multimedia

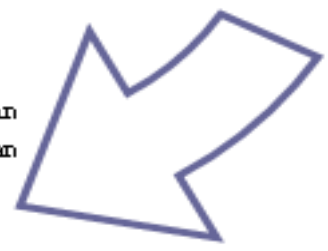

Gambar 2. Mekanisme Penerapan Model Pembelajaran di SMA N 1 Narmada 
Pelaksanaan implementasi model pembelajaran dengan memanfaatkan multimedia diawali dengan studi kelayakan. Manikowati dan Utomo (2018) melaporkan bahwa SMA Negeri 1 Narmada merupakan salah satu sekolah yang layak untuk menerapkan model pembelajaran dengan memanfaatkan TIK, khususnya multimedia. Dari data yang diperoleh, Kepala sekolah memiliki kebijakan yang terbuka terhadap pemanfaatan TIK untuk pembelajaran meskipun jumlah perangkat yang dimiliki masih kurang memenuhi kuota siswa. Selain itu, terdapat informasi bahwa pemanfaatan TIK di sekolah ini sudah berjalan dengan cukup baik. Sebagai tambahan, beberapa guru di sekolah ini sudah menerapkan model pembelajaran meskipun masih ada beberapa model pembelajaran inovatif yang belum diketahui dan kemampuan TIKnya masih pada tataran literasi. Berdasarkan kondisi yang diperoleh, SMA Negeri 1 Narmada berada pada level literated infusing (masih ada beberapa model pembelajaran inovatif yang belum diketahui tetapi TIK dapat dimanfaatkan meski belum didukung oleh kompetensi TIK yang bagus dari para guru). Memperhatikan kondisi tersebut, akhirnya diputuskan bahwa yang menjadi target capaian penerapan di sekolah tersebut adalah implemented infusing (Pengetahuan guru terhadap model pembelajaran inovatif semakin meningkat dibarengi kemampuan TIK yang baik oleh para guru sehingga dapat diterapkan dan dimanfaatkan dalam proses pembelajaran).

Pada tahap orientasi, dilakukan penyampaian kondisi sekolah tersebut dan kesepakatan untuk menentukan peran antara BPMPK, Dinas Pendidikan Provinsi NTB, dan SMA Negeri 1 Narmada agar target pencapaian dapat terpenuhi sesuai perencanaan. BPMPK menurut Manikowati dan Utomo (2018) memiliki peran untuk mendampingi sekolah sampai pengetahuan guru terhadap model-model pembelajaran inovatif dan kemampuan TIK guru dalam mengembangkan dan memanfaatkannya meningkat. Untuk itu, BPMPK memfasilitasi guru dengan memberikan bimbingan teknis pengembangan dan pemanfaatan TIK, memberikan layanan konsultasi jika diperlukan, dan melakukan pemantauan. Bimbingan teknis pengembangan media pembelajaran video pun diberikan kepada para guru model. Demikian pula pemanfaatan multimedia pembelajaran yang berada di Rumah belajar dan m-edukasi. Untuk memudahkan komunikasi antara ketiga pihak yang terkait dalam penerapan model pembelajaran ini, maka dibuatlah Whatsapp group. Melalui sosial media tersebut, BPMPK memberikan kesempatan kepada sekolah untuk berkonsultasi jika memang diperlukan dan mengunggah pelaksanaan pembelajaran yang terintegrasi TIK serta kepada dinas pendidikan untuk berkoordinasi secara intensif. Dinas Pendidikan Provinsi NTB memiliki peran untuk membantu BPMPK dalam melakukan pemantauan secara dekat dan berkoordinasi dengan memanfaatkan media komunikasi. Sementara, sekolah memiliki peran untuk terus mengupayakan pengembangan kompetensi guru dan melaksanakan pembelajaran yang terintegrasi dengan TIK serta melakukan komunikasi baik dengan BPMPK maupun dengan Dinas Pendidikan Provinsi secara baik dan intensif.

Manikowati dan Utomo (2018) menyampaikan bahwa pada saat melakukan sosialisasi, BPMPK memberikan informasi kepada kedua pihak lainnya yang terlibat dalam penerapan model pembelajaran mengenai model pembelajaran blended-learning, termasuk flipped-classroom. Bahkan, BPMPK memberikan gambaran pelaksanaan model pembelajaran flipped-classroom beserta contoh penerapannya dalam sebuah modul yang akhirnya di-share melalui WA group.

Berikutnya, sebagai upaya peningkatan kompetensi TIK guru, BPMPK memberikan bimbingan teknis pengembangan media pembelajaran berbasis video. Harapannya, para guru model dapat membuat video-video sederhana untuk mengoptimalkan pembelajaran yang diselenggarakan. Tak hanya itu, para guru model pun diberikan bimbingan teknis bagaimana memanfaatkan sumber-sumber 
belajar yang ada di Rumah belajar dan m-edukasi untuk digunakan dalam proses belajar mengajar. Dengan mendapatkan bekal tersebut, diharapkan pembelajaran menjadi lebih berkualitas.

Hasil pembekalan merupakan amunisi persenjataan bagi para guru model untuk menjalankan perannya di dalam pembelajaran yang dilaksanakan. Dalam implementasi blended- learning, termasuk dengan tipe flipped-classroom, guru model berupaya untuk memfasilitasi siswanya dengan kebutuhan materi yang tepat. Guru model dapat memberikan media pembelajaran yang dikembangkan untuk dipelajari siswanya di luar kelas. Pun memberikan sumber-sumber belajar yang dapat dijadikan sebagai referensi untuk mempelajari suatu topik atau pokok materi yang hendak dibahas nantinya di dalam kelas. Siswa di-setting menjadi pebelajar yang aktif, berupaya mencari data dan informasi berdasarkan kebutuhan pembelajaran yang harus dikuasai, dan berusaha mensintesa apa yang dipelajarinya di rumah dari multi media yang dimanfaatkannya. Dari kondisi tersebut terlihat terjadi pergeseran peran antara guru dan siswa. Guru bukanlah satu-satunya sumber belajar bagi siswa tetapi multi media dapat menjadi sumber belajar bagi siswa sebagai pebelajar aktif. Pergeseran peran ini sebagaimana disampaikan oleh Aksoy (2013) pada tabel berikut.

Tabel 1. Peran Guru dan Siswa

\begin{tabular}{ll}
\hline Peran Guru & Peran Siswa \\
\hline Fasilitator & Peneliti Proaktif \\
\hline Pembimbing & Pencari Kebutuhan \\
\hline Konselor & Pebelajar aktif \\
\hline Penasihat & Pembangun Pengetahuan \\
\hline Perancang Pembelajaran & \\
\hline
\end{tabular}

Dengan pergeseran peran tersebut, keterampilan berfikir (Higher Order Thinking Level) siswa akan lebih meningkat. Aktivitas-aktivitas pembelajaran yang diselenggarakan dengan memanfaatkan multimedia tersebut selanjutnya disampaikan secara periodik sebagai bentuk pemantauan, meskipun diselenggarakan secara online.

Pemantauan secara langsung (offline) dilaksanakan sekaligus sebagai evaluasi formatif. Kegiatan ini berfungsi sebagai pengendalian terhadap proses pembelajaran yang diselengggarakan sekaligus sebagai upaya untuk memperbaikinya apabila terdapat kekurangan di dalam praktiknya. Hal senada disampaikan oleh Ediyanto (2016) bahwa tujuan penilaian formatif adalah untuk memperbaiki proses pembelajaran, bukan hanya untuk menentukan tingkat kemampuan siswa. Selain itu, penilaian formatif bertujuan untuk memperoleh informasi mengenai kekuatan dan kelemahan pembelajaran yang telah dilakukan dan menggunakan informasi tersebut untuk memperbaiki, mengubah atau memodifikasi pembelajaran agar lebih efektif dan dapat meningkatkan kompetensi siswa. Apalagi, kondisi pada saat pelaksanaan pemantauan ini, SMA Negeri 1 Narmada secara infrastruktur menjadi terganggu. Berikut adalah sedikit gambaran kondisi pembelajaran di sekolah pada saat pemantauan berlangsung. 


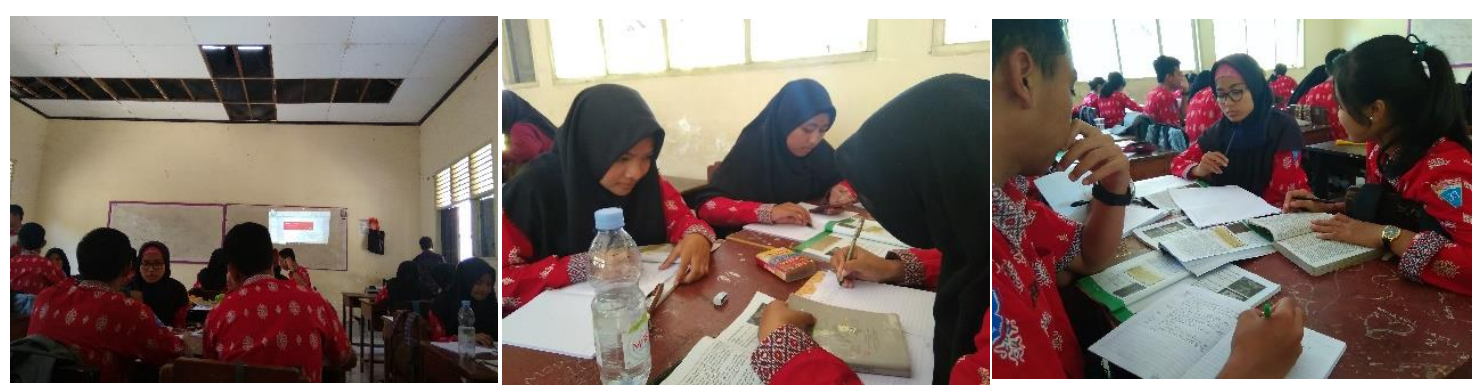

Gambar 3. Kondisi Pembelajaran di SMA N 1 Narmada Pasca Gempa Bumi

Meskipun mendapati kondisi tersebut, tidak menyurutkan civitas sekolah dalam menyelenggarakan pembelajaran. Dengan jaringan internet yang tetap baik di Nusa Tenggara Barat dan perangkat teknologi yang bisa digunakan, maka model pembelajaran flipped-classroom menjadi alternatif model pembelajaran yang efektif untuk diimplementasikan.

Pada pemantauan ini, evaluasi formatif terhadap penerapan model flipped classroom dilakukan pada mata pelajaran bahasa Inggris. Topik pembelajaran yang disampaikan adalah mengenai "Caption Text".

\section{Analisis Persiapan Pembelajaran}

Berdasarkan RPP yang diterima, topik "Caption Text" tersebut disampaikan selama 4 jam pelajaran atau $4 \times 45$ menit, yang dibagi menjadi dua kali pertemuan. Kompetensi Inti (KI) dan Kompetensi Dasar (KD) beserta indikator pencapaian pembelajaran termuat secara jelas di RPP. Pernyataan tujuan pembelajaran juga sesuai dengan pola baku ABCD- Audience, Behaviour, Condition, dan Degree. Keempat unsur tersebut tercakup di dalam tujuan pembelajaran. Berikut adalah pernyataan tujuan pembelajaran yang terdapat pada RPP guru model.

Melalui pendekatan saintifik, metode discovery learning, teknik membaca skimming dan scanning, dan melalui tayangan LCD yang dipadu dengan beberapa aplikasi, peserta didik dapat menganalisis fungsi sosial, struktur teks, dan unsur kebahasaan dari teks penyerta gambar, sesuai dengan konteks penggunaannya, menangkap makna dalam teks penyerta gambar, dan menyusun teks penyerta gambar, dengan memperhatikan fungsi sosial, struktur teks, dan unsur kebahasaan yang benar dan sesuai konteks dengan perilaku jujur, disiplin, tanggungjawab, peduli (gotong royong, kerjasama, toleran, damai), santun, responsif dan pro-aktif dan menunjukan sikap sebagai bagian dari solusi atas berbagai permasalahan dalam berinteraksi secara efektif dengan lingkungan sosial dan alam serta dalam menempatkan diri sebagai cerminan bangsa dalam pergaulan dunia.

Meskipun demikian, terlihat guru penyusun RPP masih kebingungan dalam memahami konsep strategi dan metode pembelajaran. Hal ini terlihat pula pada poin pendekatan/ model/ metode pada RPP-nya. 


\section{E. Pendekatan/ Model/ Metode \\ -Pendekatan saintifik \\ F. Media Pembelajaran \\ a. LCD dan Gambar contoh teks penyerta gambar \\ G. Sumber/Bahan \\ Buku siswa dan buku guru Bahasa Inggris Kelas XII SMA/MA yang diterbitkan oleh kemendikbud}

Gambar 4. Tampilan Pendekatan, Media, dan Sumber pada RPP

Kekurangan juga terdapat pada poin media pembelajaran. Terlihat pada RPP, guru tersebut masih belum memahami benar konsep media dan alat pembelajaran. Kekurangan juga terlihat di sumber atau bahan. Sama halnya kebanyakan guru. Guru model ini pun hanya mencantumkan buku sebagai sumber atau bahan belajar. Sementara, ada banyak macam sumber/ bahan belajar yang bisa digunakan.

Strategi pembelajaran yang akan diterapkan dalam model pembelajaran yang dipilih selanjutnya direncanakan tahap demi tahap dalam RPPnya, terutama pada poin Langkah Kegiatan Pembelajaran. Berikut adalah kegiatan pembelajaran yang direncanakan oleh guru model dalam mengajarkan topik "Caption Text" dalam dua kali pertemuan (2 x 45 menit).

Memperhatikan kegiatan pembelajaran yang direncanakan, terlihat bahwa flipped-classroom diterapkan dalam proses pembelajaran yang diselenggarakan. Pada pertemuan 1 , di kegiatan penutup jelas dicantumkan dalam RPP bahwa guru meminta siswa untuk melakukan browsing dan mempelajari kembali mengenai struktur teks dan language features teks penyerta (caption text) dan mencari dua buah contoh gambar di rumah dan mengumpulkannya melalui email atau media sosial. Konsekuensinya, guru mengunduh, mengidentifikasi, dan memodifikasi gambar yang dikirimkan siswa menjadi media baru. Pada pertemuan 2, dicantumkan rencana pada kegiatan pendahuluan bahwa guru menanyangkan caption text dari gambar yang dikirimkan. Selanjutnya, pada kegiatan inti, yakni pada tahap mengamati guru mencantumkan secara jelas penggunaan TIK dari gambar yang dikirim siswa melalui email. Pada tahap mengumpulkan informasi, siswa diminta menguraikan secara lisan dengan bahasa sendiri. Jika disederhanakan ke dalam pola strategi penerapan flipped-classroom yang disampaikan oleh Braseby (2014), maka pola penerapannya dapat digambarkan sebagai berikut.

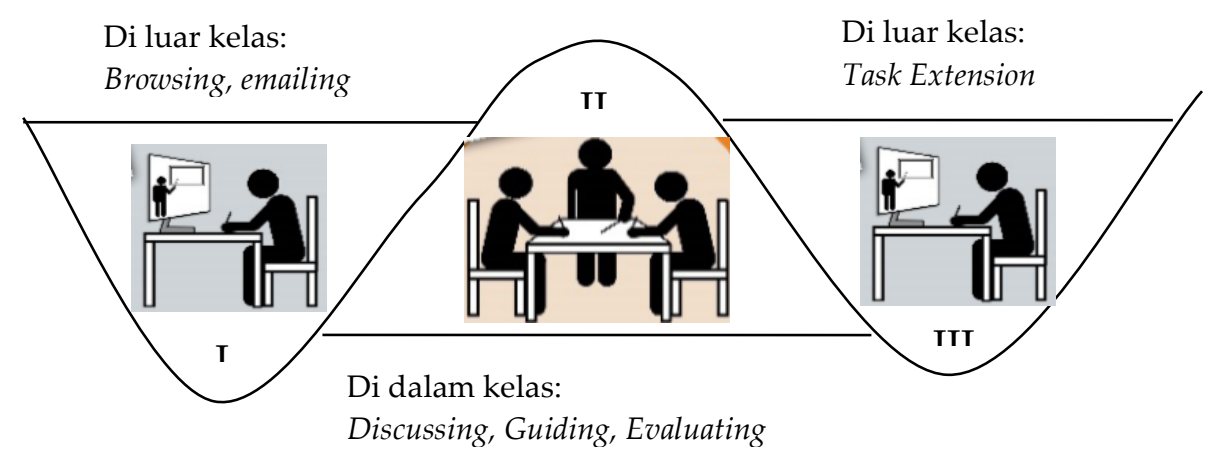

Gambar 5. Pola Penerapan Flipped-Classroom 
Dari analisis persiapan tersebut hasilnya terlihat bahwa guru model sudah mempersiapkan pembelajaran yang akan disampaikan. Flipped classroom direncanakan agar waktu pembelajaran lebih efesien dan siswa lebih siswa untuk menerima pembelajaran di kelas sehingga proses pembelajaran diharapkan akan lebih efektif. Perbaikan pengetahuan kepada guru model diutamakan untuk memberikan pengetahuan kepada beliau mengenai model, strategi, dan metode pembelajaran. Terlihat dalam RPP, guru model belum mencantumkan model pembelajaran yang dipakai beserta sintaksnya.

\section{Observasi Proses Pembelajaran}

Pembelajaran yang diselenggarakan guru model pada saat pemantauan ini adalah pembelajaran untuk pertemuan ke-2 mengenai Caption Text. Sebelum dimulai, guru model menyetting terlebih dahulu peralatan dan media yang akan digunakan. Beliau memasang laptop dan memastikan LCD yang digunakan dapat beroperasi dengan baik.

Pada awal proses pembelajaran, guru model memberikan salam dan menanyakan kondisi kesehatan para siswa. Kemudian, beliau mengulas pembelajaran yang telah laksanakan sebelumnya. Selanjutnya, dengan menggunakan video scribe yang telah dibuat, beliau menampilkan kepada siswa tentang caption text dari tugas yang telah dikirimkan siswa saat di rumah.

Pada kegiatan inti, siswa diminta mengamati media yang ditayangkan. Selanjutnya, diminta menjawab pertanyaan seputar fungsi dan struktur caption text beserta language features-nya. Dalam hal ini siswa diberikan beberapa contoh caption text agar mereka dapat mengumpulkan informasi dan mengasosiasikannya. Terakhir, beberapa siswa ditunjuk oleh guru model untuk menyampaikan hasil belajar mereka secara lisan.

Pada kegiatan penutup, guru memandu saja para siswa untuk mereview pembelajaran yang telah dilaksanakan. Berikut adalah proses pembelajaran yang diselenggarakan dengan model flippedclassroom memanfaatkan multi media berbasis TIK.

Tabel 2. Tahapan Implementasi Flipped Classroom Terobservasi

\begin{tabular}{|c|c|c|c|c|}
\hline \multirow{2}{*}{$\begin{array}{l}\text { Pertemuan } \\
\text { ke- }\end{array}$} & \multirow{2}{*}{$\begin{array}{c}\text { Tahap } \\
\text { Kegiatan }\end{array}$} & \multicolumn{2}{|c|}{ Proses Pembelajaran } & \multirow[t]{2}{*}{ Metode } \\
\hline & & Guru & Siswa & \\
\hline \multirow[t]{2}{*}{ I } & Penutup & $\begin{array}{l}\text { Guru menugaskan } \\
\text { siswa mencari/ } \\
\text { browsing dua contoh } \\
\text { caption teks melalui } \\
\text { internet dan } \\
\text { mengemailkannya. }\end{array}$ & $\begin{array}{l}\text { Siswa mencari/ browsing } \\
\text { dua contoh caption teks } \\
\text { melalui internet di rumah } \\
\text { dan mengemailkannya. }\end{array}$ & Penugasan \\
\hline & & $\begin{array}{l}\text { Guru mengunduh } \\
\text { caption teks yang } \\
\text { dikirimkan siswa dan } \\
\text { membuat media baru } \\
\text { untuk digunakan } \\
\text { dalam pertemuan } \\
\text { berikutnya. }\end{array}$ & & \\
\hline
\end{tabular}




\begin{tabular}{|c|c|c|c|c|}
\hline II & Pembuka & $\begin{array}{l}\text { Guru memberikan } \\
\text { apersepsi kepada } \\
\text { para siswa dengan } \\
\text { menayangkan video } \\
\text { scribe. }\end{array}$ & $\begin{array}{l}\text { Para siswa menjawab } \\
\text { pertanyaan guru dari video } \\
\text { scribe yang ditayangkan. }\end{array}$ & Tanya jawab \\
\hline & \multirow[t]{3}{*}{ Inti } & $\begin{array}{l}\text { Guru meminta para } \\
\text { siswa mengamati } \\
\text { caption text dari video } \\
\text { scribe yang } \\
\text { ditanyangkan. }\end{array}$ & $\begin{array}{l}\text { Para siswa mengamati } \\
\text { contoh-contoh caption text } \\
\text { dari video scribe yang } \\
\text { ditayangkan, struktur text } \\
\text { dan language featuresnya. }\end{array}$ & observasi \\
\hline & & $\begin{array}{l}\text { Guru meminta para } \\
\text { siswa mengumpulkan } \\
\text { informasi mengenai } \\
\text { caption text dari video } \\
\text { scribe yang telah } \\
\text { ditanyangkan dan } \\
\text { mengasosiasikannya }\end{array}$ & $\begin{array}{l}\text { Para siswa mengumpulkan } \\
\text { informasi mengenai caption } \\
\text { text dari video scribe yang } \\
\text { telah ditanyangkan dan } \\
\text { mengasosiasikannya } \\
\text { dengan teman sebangku. }\end{array}$ & Diskusi \\
\hline & & $\begin{array}{l}\text { Guru meminta siswa } \\
\text { untuk } \\
\text { mengkomunikasikan } \\
\text { hasil belajarnya } \\
\text { secara lisan. }\end{array}$ & $\begin{array}{l}\text { Siswa mengkomunikasikan } \\
\text { hasil belajarnya secara } \\
\text { lisan. }\end{array}$ & Demonstrasi \\
\hline & \multirow[t]{2}{*}{ Penutup } & $\begin{array}{l}\text { Guru mereview topik } \\
\text { pembelajaran yang } \\
\text { telah dilaksanakan. }\end{array}$ & $\begin{array}{l}\text { Siswa menjawab setiap } \\
\text { umpan pertanyaan yang } \\
\text { diberikan guru. }\end{array}$ & Tanya jawab \\
\hline & & $\begin{array}{l}\text { Guru meminta siswa } \\
\text { menyusun Caption } \\
\text { Text di rumah. }\end{array}$ & $\begin{array}{l}\text { Siswa membuat Caption } \\
\text { Text di rumah dan } \\
\text { mengumpulkannya }\end{array}$ & \\
\hline
\end{tabular}

\section{Keterangan:}

Kolom dengan latar berwarna, pembelajaran dilaksanakan di rumah

Kolom dengan latar tak berwarna, pembelajaran dilakukan di kelas.

Berdasarkan observasi penyelenggaraan proses pembelajaran dengan model flipped classroom ini ternyata memberikan manfaat kepada siswa maupun gurunya. Bagi siswa, tanggung jawab moralnya sebagai siswa menjadi tumbuh. Dengan model ini siswa secara tidak langsung dituntut untuk aktif melengkapi dirinya dengan pengetahuan sebelum belajar di sekolah. Selain itu, siswa juga secara tidak langsung diadaptasikan untuk menggunakan perangkat elektronik yang mereka punya, HP atau laptop secara bijak untuk pembelajaran. Karlson dan Janson (2016) menyatakan manfaat flipped-classroom adalah: 1) memberikan struktur pembelajaran menyatu (blended learning); 2) memberi kesempatan 
menggunakan perangkat multimedia untuk pembelajaran online; 3) mengklarifikasi konsep-konsep yang kurang sesuai; dan 4) meningkatkan interaksi dan integrasi siswa terhadap topik yang dibelajari.

Manfaat bagi guru adalah setidaknya mampu mengetahui kemampuan awal siswanya, heterogenitas performa siswanya sehingga guru dapat menyiapkan strategi pembelajaran yang terbaik untuk mengakomodir seluruh siswanya. Berikutnya, beliau dapat mempersiapkan media yang dapat digunakan untuk memfasilitasi pembelajaran yang dilaksanakan. Artinya, empat pilar utama model flpped-classroom yang selanjutnya oleh Flipped Learning Network (Brown, 2016) dapat terimplementasi dengan baik. Keempat pilar tersebut adalah "FLIP" yang kepanjangan dari F, flexible environment (lingkungan yang fleksibel), L, learning culture shift (pergeseran budaya belajar), I, intentional content (konten yang dirancang dengan baik), dan $\mathbf{P}$, proffesional educator (pendidik yang profesional).

Berhubungan dengan pemanfaatan media yang digunakan, video yang digunakan oleh guru model sebenarnya sudah sangat mendukung. Komponen konten pembelajaran sudah tercakup dalam media tersebut. Akan tetapi, kendala hanya terjadi pada setting peralatan belajar saja. Proyeksi LCD tidak tampil secara optimal sehingga siswa yang duduk di belakang harus benar-benar fokus.

\section{Hasil Wawancara Guru Model}

Wawancara dengan guru model terhadap penerapan model pembelajaran flipped classroom merupakan data dukung yang dibutuhkan untuk mengendalikan kondisi pembelajaran yang diselenggarakan. Berdasarkan wawancara diperoleh data mengenai motivasi pemanfaatan TIK dalam pembelajaran, team working civitas akademika sekolah dalam menyelenggarakan model pembelajaran yang diterapkan, pelaksanaan penerapan, manfaat dan kendala penerapan model dan pemanfaatan TIK dalam pembelajaran.

Dari data yang diperoleh, para guru sebenarnya sangat mendukung pemanfaatan TIK dalam pembelajaran karena sangat bermanfaat apabila digunakan sesuai yang seharusnya. Penggunaan laptop di kelas sangat membantu guru dalam memberikan visualisasi materi kepada para siswa. Pembelajaran lebih menarik karena dapat memanfaatkan banyak indra. TIK dapat digunakan untuk melakukan simulasi dan demonstrasi, terutama jika bahan dan alat yang dibutuhkan tidak dimiliki sekolah. Pemanfaatan media sosial dan atau email juga sangat membantu guru untuk mengefisiensikan pembelajaran yang diselenggarakan. Akan tetapi, penerapan model flipped classroom ini masih mengalami kendala karena membutuhkan persiapan lebih, biaya yang lebih, mudah disalahgunakan, dan sulit mengontrol pemakainya. Apalagi SMA 1 Narmada merupakan salah satu sekolah yang mengalami dampak gempa yang cukup parah. Hal ini membutuhkan team work yang baik, baik antar guru maupun guru dengan tenaga kependidikan lainnya. Di SMA 1 Narmada, team working ini sudah terjalin, meskipun belum optimal partisipasinya.

Memperhatikan data yang diperoleh, para guru sebenarnya merasa terdukung ketika TIK dimanfaatkan dalam pembelajaran pun dengan menerapkan model flipped classroom. Apalagi, dalam pembelajaran yang diselenggarakan pasca gempa. Kekurangan waktu yang dialami SMA 1 Narmana dapat diantisipasi dengan model ini. Akan tetapi, pelaksanaannya belum optimal karena belum optimalnya team working sumber daya manusia dan tingkat kesulitan yang dihadapi untuk persiapan maupun pengontrolan pembelajaran. Selain itu, kebutuhan yang lebih atas fasilitas sarana dan prasarana yang dibutuhkan juga menjadi kendala penerapannya. 


\section{Hasil Wawancara Kepala Sekolah}

Wawancara dengan kepala sekolah dilaksanakan untuk memperoleh data mengenai kebijakan kepala sekolah terhadap penerapan blended learning tipe flipped classroom dengan memanfaatkan multi media berbasis TIK. Data ini merupakan data dukung untuk mengendalikan model pembelajaran yang diterapkan.

Kepala sekolah dan seluruh civitas SMA 1 Narmada pada hakikatnya mendukung penerapan model blended learning, terutama tipe flipped classroom. Beliau sangat terbuka sekali terhadap pemanfaatan fasilitas sekolah seperti internet, laptop, LCD, dan lab komputer untuk pembelajaran dan pengelolaan sekolah. Bahkan, beliau mempersilakan siswa untuk memanfaatkan handphone untuk pembelajaran dengan catatan di bawah pengawasan guru.

Dari data tersebut terlihat bahwa SMA 1 Narmada memiliki kebijakan yang baik sekali terhadap penerapan model blended learning tipe flipped classroom dengan mengggunakan multi media berbasis TIK. Dukungan terhadap pemanfaatan sarana dan prasarana yang dimiliki sekolah untuk pembelajaran dimaksimalkan. Selain itu, kebijakan terhadap pemakaian handphone pun diijinkan agar pembelajaran yang diselenggarakan bisa optimal. Akan tetapi, masih di bawah pengawasan guru.

\section{KESIMPULAN DAN SARAN} berikut:

Memperhatikan data dan informasi yang diperoleh, dapat disimpulkan beberapa hal sebagai

1. Penerapan model blended learning, terutama pada model flipped classroom dengan memanfaatkan multi media berbasis TIK dapat dilaksanakan dengan baik. Guru mempersiapkan Rencana Pelaksanaan Pembelajaran (RPP) sebelum mengajar, melaksanakan pembelajaran sesuai rencana, dan menggunakan multimedia sesuai dengan kebutuhan topik yang disampaikan.

2. Secara umum guru yang menjadi model penerapan di SMA Narmada sudah mampu membuat RPP dengan baik. Akan tetapi, masih perlu di-upgrade pengetahuan mereka mengenai perbedaan antara strategi, model, dan metode pembelajaran.

3. Kemampuan guru untuk menerapkan model pembelajaran pun sudah baik. Guru dalam mengajar sudah sesuai dengan RPP yang dipersiapkan dan mampu menggunakan multimedia berbasis TIK dengan baik dan lancar serta sesuai kebutuhan pembelajaran.

4. Kemampuan menyetting peralatan seperti LCD proyektor masih kurang.

5. Guru siap untuk mengimplementasikan model pembelajaran flipped classroom dengan memanfaatakan multi media berbasis TIK. Hal ini karena TIK membantu guru dalam meningkatkan motivasi siswa dalam belajar.

6. Flipped classroom menjadikan pembelajaran yang diselenggarakan menjadi lebih efisien. Akan tetapi, pelaksananaannya harus tetap dalam pengawasan guru.

Berdasarkan kondisi yang ada disarankan kepada para guru untuk lebih meningkatkan profesionalitas mereka dalam pembelajaran (pemahaman mengenai strategi, model, dan metode pembelajaran) dan pemanfaatan TIK untuk pembelajaran. Selain itu, kerjasama dengan pendidik dan 
tenaga pendidikan juga diperlukan untuk meningkatkan sinergi dalam menerapkan model pembelajaran dengan memanfaatkan multi media berbasis TIK sehingga diharapkan pembelajaran lebih efektif dan efisien. Kebijakan Kepala Sekolah untuk terbuka terhadap pemanfaatan TIK juga sangat diharapkan untuk mengoptimalkan pembelajaran yang diselenggarakan. Pemantauan dan pengontrolan terhadap para guru dalam menerapkan model-model e-pembelajaran juga perlu dilakukan secara kontinu agar terjadi peer-learning. Salah satu caranya adalah dengan mengadakan sharing program. Tak kalah penting yang perlu dilakukan SMA N 1 Narmada adalah dengan melakukan parenting dengan para wali murid. Tujuannya untuk mengajak para orang tua untuk terbuka terhadap perkembangan teknologi sekaligus turut serta mengontrol pemanfaatan teknologi yang digunakan para siswa. Kepada BPMPK disarankan untuk tetap menjadi mitra sekolah dalam menerapkan model-model pembelajaran dengan memanfaatkan multi media berbasis TIK.

\section{DAFTAR PUSTAKA}

Aksoy, E. (2013). Flipped Classroom. Diakses 18 Oktober 2019. Online: https://ctl.tedu.edu.tr/sites/default/files/content_files/docs/flipped_model.pdf

Bergmann, J., \& Sams, A. (2013). The Flipped Classroom. CSE, 17(3), 24-27. Online: www.acsi.org

Braseby, A. M. (2014). The Flipped-Classroom. Diakses 18 Oktober 2019. Online: https://www.ideaedu.org

Brown, B. A (2016). Understanding the flipped classroom: Types, uses, and reactions to a modern and evolving pedagogy. Culminating Projects in Teacher Development, 12, 1-26. Online: https://repository.stcloudstate.edu/cgi/viewcontent.cgi?referer=https://www.google.com/\&httpsredi $r=1 \&$ article $=1010$ \&context=ed_etds

Daryanto, A. (2015). Blended Learning Models for Graduate Programs of Management and Business. Presented on Online and Blended Education for MM/MBA Programs. Telkom University Bandung. Unpublished

Ediyanto. (2016). Penilaian Formatif dan Penilaian Sumatif. Diakses 18 Oktober 2019. Online: https://yudharta.ac.id/id/2016/11/penilaian-formatif-dan-penilaian-sumatif/

Karlsson, G., \& Janson, S. (2016). The Flipped Classroom: A Model for Active Student Learning. Sweden: Portland Press Limited

Manikowati \& Utomo, N. P. (2018). Sosialisasi Penerapan Model Pembelajaran Blended-Learning Dengan Memanfaatkan Multimedia: Laporan. Semarang: BPMPK. Unpublished

Manikowati \& Utomo, N. P. (2018). Pemantauan Penerapan Model Pembelajaran Blended-Learning Dengan Memanfaatkan Multimedia: Laporan. Semarang: BPMPK. Unpublished

Millman, N. B. (2012). The flipped classroom strategy: What is it and how can it best be used? Distance Learning, 9(3), 85-87.

Mulyadi, D. (2015). Study Kebijakan Publik dan Pelayanan Publik. Bandung : Alfabeta.

Tahir, A. (2015). Kebijakan Publik dan Transparansi Penyelenggaraan Pemerintah Daerah. Bandung: Alfabeta. 
Jurnal Penelitian Teknologi Pendidikan http://jurnal.uns.ac.id/Teknodika

Tiari, D. A., Suryani, N., \& Suharno. (2016). Penerapan multimedia interaktif untuk meningkatkan motivasi dan hasil belajar IPA materi struktur organ tubuh manusia dan fungsinya. Teknodika, 14(1), 22-30. 